\title{
Development and Validation of HPLC Method for Estimation of Pregabalin in Bulk \& Capsule Dosage Form
}

\section{Seema $\mathbf{A}^{*}$, Jeeja P and Ashish J}

University of Mumbai, Shri. D. D. Vispute College of Pharmacy \& Research Centre, New Panvel, Navi Mumbai, India

*Corresponding author: Seema A, Sect No. 15A, Plot No. 1, Flat No. C-003, New Panvel, Navi Mumbai, Maharashtra-410206, Tel: 8108213953/02227464448; E-mail: seemaauti.10@gmail.com

Received date: May 24, 2016; Accepted date: Jun 22, 2016; Published date: Jun 25, 2016

Copyright: (c) 2016 Seema A, et al. This is an open-access article distributed under the terms of the Creative Commons Attribution License, which permits unrestricted use, distribution, and reproduction in any medium, provided the original author and source are credited.

\begin{abstract}
A simple, rapid, specific, precise and accurate HPLC method has been developed for the estimation of Pregabalin in bulk drugs and in capsule dosage forms. The mobile phase consisted of 80: 10: 10 (v/v/v) of Disodium Hydrogen Phosphate Buffer: Acetonitrile: Methanol. The flow rate is $1 \mathrm{ml} / \mathrm{min}$. Chromatographic determination of Pregabalin was performed on Inertsil ODS -3V, C18 $(250 \times 4.6 \mathrm{~mm} \mathrm{Id}, 5 \mu \mathrm{m})$ column. The wavelength of detection is $210 \mathrm{~nm}$. The injection volume is $20 \mu \mathrm{L}$. The retention time of Pregabalin is 4.7 minutes. The developed method was validated in terms of specificity, accuracy, precision, linearity, solution stability, ruggedness, robustness and system suitability. The influence of Acid, Alkaline, Oxidative Stress, Photolytic stress, Thermal stress, and Humidity stress conditions on pregabalin was studied. Results indicated that Pregabalin is stable under the experimental conditions. The proposed method has been successfully used for the routine analysis of pregabalin in capsule dosage forms.
\end{abstract}

Keywords: HPLC; Pregabalin; Estimation; Bulk drug; Capsule dosage form

\section{Introduction}

Pregabalin [1] chemically known as (S)-2(amino methyl)-5-methyl hexanoicacid (Figure 1), is a white crystalline solid, which is soluble in water and in both basic and acidic aqueous solution sand used as anticonvulsant, analgesic medication and neurotransmitter. [2,3] Pregabalin is the 3 isobutyl substituted analogue of $\delta$ amino butyric acid (GABA) but is inactive at GABA receptors. [4] This drug produces its actions by binding to the alpha 2 delta $(\alpha 2 \delta)$ subunit of the voltage gated calcium channels. It is well absorbed after oral administration and largely excreted by renal excretion [5] (Figure 1).

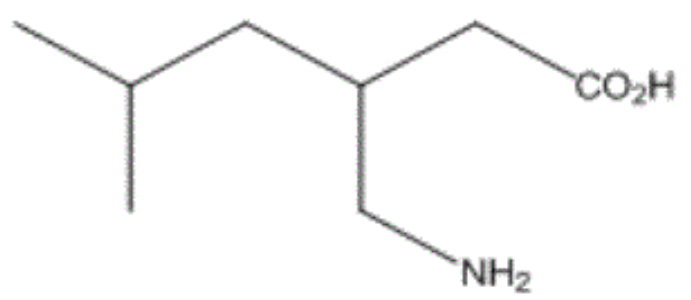

Figure 1: Structure of Pregabalin.

It was designed as a more potent successor to gabapentin. Pregabalin and gabapentin bind with high affinity to $\alpha 2 \delta$ protein, an auxiliary subunit of $\mathrm{Q}$ type voltage sensitive calcium channels in the peripheral and central nervous system. [6] Binding to $\alpha 2 \delta$ protein, results in calcium influx reduction at nerve terminals which leads to reduction of neurotransmitters such as glutamate and noradrenaline and abnormal neuronal excitability. [7,8] Pregabalin is thought to be useful for treating any other conditions, pain, physiological conditions associated with psychomotor stimulants, inflammation, gastrointestinal damage, alcoholism, insomnia, and various psychiatric disorders, including mania and bipolar disorder [9].

Pregabalin approved for a number of indications in the US and Europe that include adjunctive therapy of partial seizures in adults, pain from diabetic neuropathy or post-herpetic neuralgia in adults, and the treatment of anxiety disorders. [10] It received U.S.FDA approval for use in treating neuropathy pain and post herpetic neuralgia in 2004, appeared on the U.S market in fall 2005. [11] Recent studies have shown that pregabalin is effective at treating chronic pain in disorders such as fibromyalgia [12] and spinal card injury. [13] It is consider having a low potential for abuse, and a limited dependence liability if missed, and is thus classified as a schedule V drug in the U.S [14].

Although various bio analytical methods for estimation of pregabalin in human serum [15] and spectrophotometric method for estimation of pregabalin in dosage form [16,17] have been reported in the literature. Recently a new validated HPLC method [18] was developed for determination of pregabalin in bulk drug and capsule dosage forms. All of these methods are very expensive because these methods require long and tedious pre-treatment of the samples, laborious clean up procedures and derivatization for the analysis of pregabalin. It requires simple new HPLC method for analysis of pregabalin in bulk and the determination of pregabalin in capsules. So the attempt was made to develop a simple, efficient and selective method for the analysis of pregabalin in bulk and the determination of pregabalin in capsules. The UV detection, which is readily available in most analytical and pharmaceutical laboratories, was used for HPLC instrumentation. The developed method was validated according to the International Conference on Harmonization (ICH) guidelines. 


\section{Materials and Methods}

\section{Reagents and Chemicals}

Disodium hydrogen phosphate (AR Grade), Phosphoric acid (AR Grade), Methanol (HPLC Grade), Acetonitrile (HPLC Grade), Sodium hydroxide (AR Grade), Hydrochloric acid (AR Grade), Hydrogen peroxide (AR Grade), Waters (Mili Q), Filter paper (Whatmann-42), Filter paper (Nylon $0.45 \mu$ ), Pregabalin working Standard, Pregabalin Capsules, Pregabalin placebo.

\section{Instruments and Columns}

HPLC with UV Detector/PDA detectors, Weighing Balance, Centrifuge, Humidity chamber, Photo-stability chamber, Drying oven, pH meter, HPLC columns, Glass apparatus, Sonicator.

\section{Chromatographic Conditions}

The proposed method was performed using a liquid chromatography of model Shimadzu Lab solution. The chromatographic separation was achieved on an Inertsil ODS -3V C18 column ( $250 \mathrm{X} 4.6 \mathrm{~mm} \mathrm{Id}, 5 \mu \mathrm{m})$. The mobile phase consisted of 80: 10: $10(\mathrm{v} / \mathrm{v} / \mathrm{v})$ of Buffer: Acetonitrile: Methanol. The flow rate was 1.0 $\mathrm{ml} / \mathrm{min}$ and the detection wavelength was $210 \mathrm{~nm}$. The injection volume is $20 \mu \mathrm{L}$ and the retention time of Pregabalin is 4.7 minutes.

\section{Experimental}

\section{Preparation of Solutions}

Preparation of buffer for mobile phase: Weigh and dissolve $5.68 \mathrm{~g}$ of disodium hydrogen phosphate in $950 \mathrm{ml}$ of water, adjust the $\mathrm{pH}$ of the solution to 6.5 with phosphoric acid and dilute to $1000 \mathrm{ml}$ with water. Filter the solution through Nylon filter paper of $0.45 \mu$ filter.

Preparation of the mobile phase: Prepare a mixture of Buffer: Acetonitrile: Methanol in the ratio 80: 10: 10 sonicate and degas.

Preparation of Standard solution: Weigh and transfer $30 \mathrm{mg}$ of Pregabalin standard into a $100 \mathrm{ml}$ volumetric flask. Add $50 \mathrm{ml}$ of methanol sonicate to dissolve. Dilute up to the mark with mobile phase and mix.

Preparation of sample solution: Weigh and transfer powder (triturate of not less than 20 capsules) equivalent to $150 \mathrm{mg}$ of Pregabalin in a $100 \mathrm{ml}$ volumetric flask, add $70 \mathrm{ml}$ of the methanol, sonicate for $45 \mathrm{~min}$, cool and dilute to volume with methanol. Centrifuge / filter through suitable filter discarding first few $\mathrm{ml}$ of filtrate. Dilute $5 \mathrm{ml}$ of the filtrate to $25 \mathrm{ml}$ with mobile phase.

Analysis of Pregabalin from Capsule Dosage form: Inject $20 \mu \mathrm{l}$ of the blank (mobile phase) once (Figure 2) and standard preparation (Figure 3) in replicate. Inject $20 \mu \mathrm{l}$ of sample preparation (Figure 4) in duplicate into the HPLC, record the chromatograms, and measure the responses of the peak due to Pregabalin. Calculate the percent content of $\mathrm{mg} /$ capsule (Figure 2, 3, 4 \& 5).

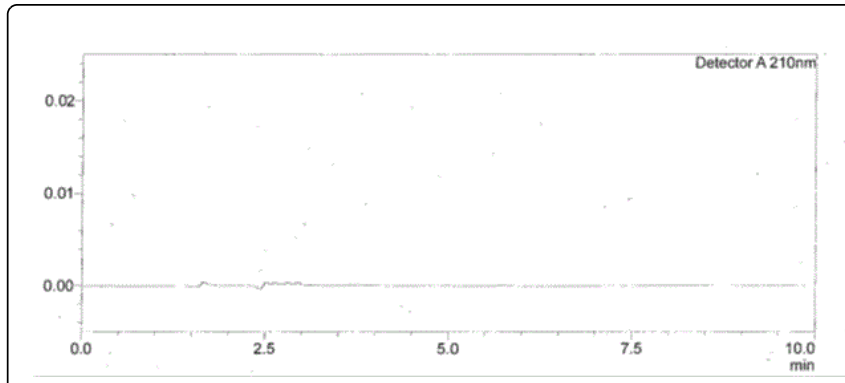

Figure 2: Chromatogram of Blank (Mobile Phase).

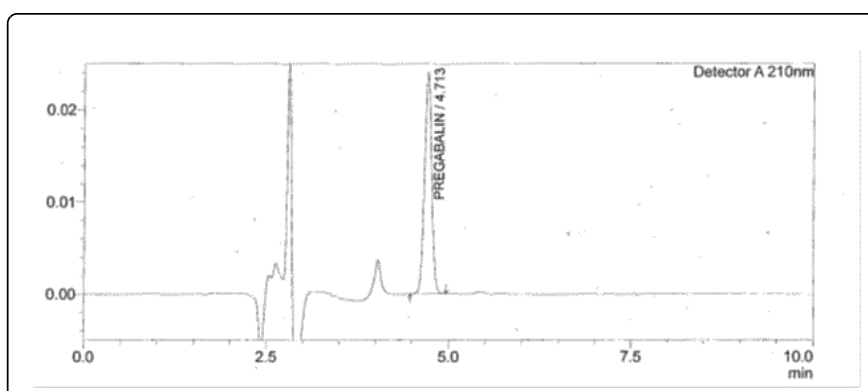

Figure 3: Chromatogram of Standard Preparation of Pregabalin.

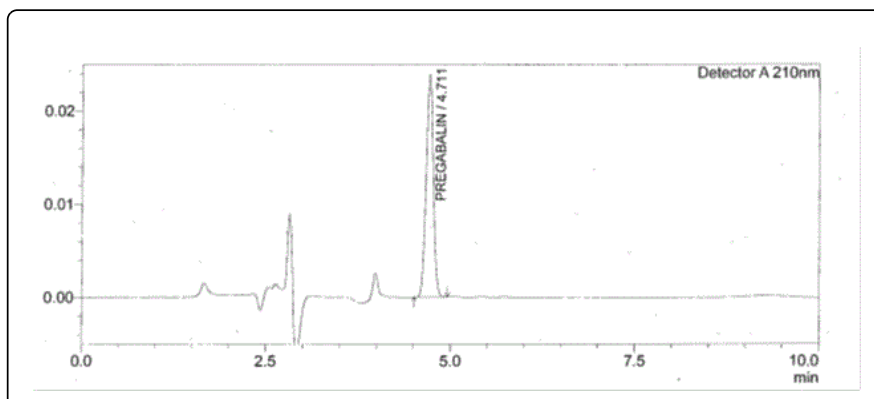

Figure 4: Chromatogram of Sample Preparation of Pregabalin.

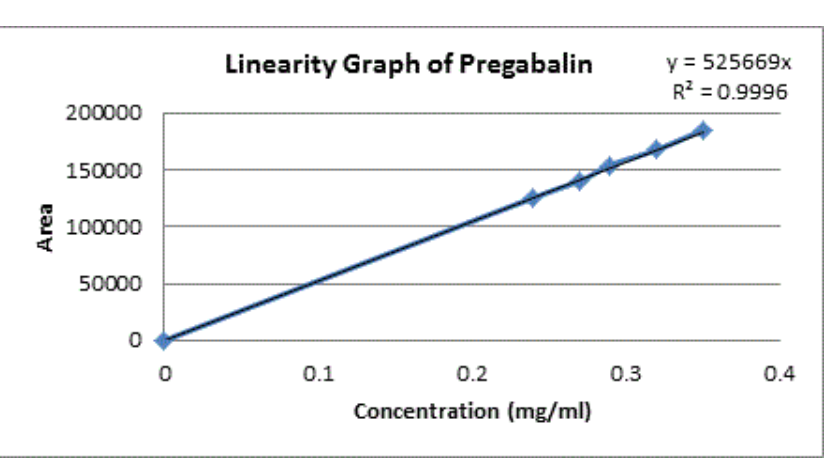

Figure 5: Linearity Graph of Pregabalin. 
Page 3 of 6

\section{Method Validation}

A full method validation was performed according to guidelines set by the ICHGuidelines. The validation of this procedure was performed in order to evaluate the method in terms of Specificity, accuracy, precision, linearity, solution stability, ruggedness, robustness and system suitability.

Specificity: Inject blank, placebo, Standard and Sample preparation. Check any interference from diluents and placebo at the Pregabalin peak.

Forced degradation: Stress the sample at the following conditions and evaluate the purity index of Pregabalin peak. Sample stress by Hydrogen Peroxide, Thermal, Humidity, Hydrochloric Acid, Sodium Hydroxide and Photo-Stability. The results are shown in the Table 1.

\begin{tabular}{|c|c|c|c|c|c|c|}
\hline S.No & $\begin{array}{l}\text { Mode of } \\
\text { degradation }\end{array}$ & Condition & $\begin{array}{l}\% \quad \text { w/w } \\
\text { Assay }\end{array}$ & $\begin{array}{l}\text { Peak } \\
\text { Threshold }\end{array}$ & $\begin{array}{l}\text { Purity } \\
\text { Index }\end{array}$ & $\begin{array}{l}\text { Peak } \\
\text { Purity }\end{array}$ \\
\hline 1 & $\begin{array}{ll}\text { As } & \text { such } \\
\text { sample }\end{array}$ & $\begin{array}{ll}\text { As } & \text { is } \\
\text { sample }\end{array}$ & 100.2 & 0.999 & 0.999 & Pass \\
\hline 2 & Acid treated & $0.1 \mathrm{~N} \mathrm{HCl}$ & 92.8 & 0.999 & 0.999 & Pass \\
\hline 3 & Base treated & $\begin{array}{l}0.1 \mathrm{~N} \\
\mathrm{NaOH}\end{array}$ & 96.3 & 0.999 & 0.999 & Pass \\
\hline 4 & $\begin{array}{l}\text { Peroxide } \\
\text { treated }\end{array}$ & $\begin{array}{ll}3 \% & \mathrm{v} / \mathrm{v} \\
\mathrm{H}_{2} \mathrm{O}_{2} & \end{array}$ & 99.5 & 0.999 & 0.999 & Pass \\
\hline 5 & $\begin{array}{l}\text { Thermal } \\
\text { treated }\end{array}$ & At $60^{\circ} \mathrm{C}$ & 98.2 & 0.999 & 0.999 & Pass \\
\hline 6 & $\begin{array}{l}\text { Humidity } \\
\text { treated }\end{array}$ & $\begin{array}{l}40^{\circ} \mathrm{C} / \\
75 \% \mathrm{RH}\end{array}$ & 97.3 & 0.999 & 0.999 & Pass \\
\hline 7 & Photo-stability & $\begin{array}{l}\text { Open } \\
\text { exposure }\end{array}$ & 99.9 & 0.999 & 0.999 & Pass \\
\hline 8 & Photo-stability & $\begin{array}{l}\text { Primary } \\
\text { pack }\end{array}$ & 100.1 & 0.999 & 0.999 & Pass \\
\hline 9 & Photo-stability & $\begin{array}{l}\text { Secondary } \\
\text { pack }\end{array}$ & 100.6 & 0.999 & 0.999 & Pass \\
\hline
\end{tabular}

Table 1: Specificity (forced degradation) results.

Linearity: Linearity shall be performed in the range from $80 \%$ to $120 \%$ of working concentration of specification limit and Y-intercept shall be noted. Linearity of pregabalin was shown in Table 2 \& Figure 5 .

\begin{tabular}{|l|l|l|}
\hline$\%$ Level & Concentration(mg/ml) & Area \\
\hline 80 & 0.24 & 125512 \\
\hline 90 & 0.27 & 140176 \\
\hline 100 & 0.29 & 154148 \\
\hline 110 & 0.32 & 167567 \\
\hline 120 & 0.35 & 184962 \\
\hline Correlation Coefficient & 0.999 & \\
\hline Y-Intercept & 525669 & \\
\hline
\end{tabular}

Table 2: Linearity.
Accuracy (Recovery): Prepare the sample solution in triplicate by spiking placebo with known standard at about 80\%, 100\% and $120 \%$ of Pregabalin to its specification limit. \% recoveries were calculated and the results are shown in the Table 3.

\begin{tabular}{|c|c|c|c|c|c|}
\hline Sample ID & $\begin{array}{l}\text { Amount } \\
\text { added- } \\
\text { mg }\end{array}$ & $\begin{array}{l}\text { Amount } \\
\text { found-mg }\end{array}$ & \%Recovery & Average & \%RSD \\
\hline Rec. $80 \%-1$ & 120.19 & 118.95 & 99 & & \multirow{3}{*}{0.15} \\
\hline Rec. $80 \%-2$ & 120.1 & 119.28 & 99.3 & 99.2 & \\
\hline Rec. $80 \%-3$ & 121.01 & 120.01 & 99.2 & & \\
\hline Rec. $100 \%-1$ & 149.44 & 148.04 & 99.1 & & \multirow{3}{*}{0.23} \\
\hline Rec. $100 \%-2$ & 149.5 & 148.17 & 99.1 & 99 & \\
\hline Rec.100\%-3 & 148.61 & 146.74 & 98.7 & & \\
\hline Rec. $120 \%-1$ & 180.95 & 180.66 & 99.8 & \multirow{3}{*}{99.8} & \multirow{3}{*}{0.25} \\
\hline Rec.120\%-2 & 180.84 & 180.11 & 99.6 & & \\
\hline Rec. $120 \%-3$ & 180.55 & 180.8 & 100.1 & & \\
\hline \multicolumn{4}{|c|}{ Overall Average } & \multicolumn{2}{|l|}{99.3} \\
\hline \multicolumn{4}{|l|}{ Overall SD } & \multicolumn{2}{|l|}{0.44} \\
\hline \multicolumn{4}{|c|}{ Overall \%RSD } & \multicolumn{2}{|l|}{0.44} \\
\hline
\end{tabular}

Table 3: Accuracy (Recovery).

System Precision: Prepare the standard solution as per the method and inject in replicates as per the method. Calculate the tailing factor and theoretical plate from the first standard chromatograph (Table 4).

\begin{tabular}{|l|l|}
\hline Sample ID & Area Response \\
\hline Injection -1 & 164140 \\
\hline Injection -2 & 163998 \\
\hline Injection -3 & 163977 \\
\hline Injection -4 & 163847 \\
\hline Injection -5 & 163717 \\
\hline Average & 163936 \\
\hline SD & 160 \\
\hline \%RSD & 0.1 \\
\hline
\end{tabular}

Table 4: System Precision.

Method precision: Prepare 6 samples of single batch and analyze the same as per the test method and calculate the \% RSD of \% Assay (Table 5).

\begin{tabular}{|l|l|}
\hline Sample ID & \% Pregabalin \\
\hline Sample -1 & 99.1 \\
\hline Sample -2 & 98.9 \\
\hline Sample -3 & 98.7 \\
\hline
\end{tabular}


Citation: Seema A, Jeeja P and Ashish J (2016) Development and Validation of HPLC Method for Estimation of Pregabalin in Bulk \& Capsule

Page 4 of 6

\begin{tabular}{|l|l|}
\hline Sample -4 & 98.9 \\
\hline Sample -5 & 98.8 \\
\hline Sample -6 & 98.8 \\
\hline Average & 98.9 \\
\hline SD & 0.14 \\
\hline \%RSD & 0.14 \\
\hline
\end{tabular}

Table 5: Method Precision.

Stability in analytical solution: Prepare one sample as per test method and inject in duplicate into HPLC at initial and at different time intervals up to $24 \mathrm{hrs}$. Determine the \% Assay at different time interval samples (Table 6).

\begin{tabular}{|l|l|}
\hline Time interval & \% Pregabalin \\
\hline Initial & 99.1 \\
\hline $6 \mathrm{hrs}$ & 99 \\
\hline $10 \mathrm{hrs}$ & 98.1 \\
\hline $24 \mathrm{hrs}$ & 98.6 \\
\hline Correlation (6hrs Initial) & 1 \\
\hline Correlation (10hrs Initial) & 0.99 \\
\hline Correlation (24hrs Initial) & 0.99 \\
\hline
\end{tabular}

Table 6: Solution stability.

Ruggedness: Perform precision of test method by different analyst by using different column, different system (HPLC) on different day.

Evaluate the system suitability criteria. Calculate the \% RSD of \% Assay of six samples; calculate the overall \% RSD of \% Assay of twelve samples between two analysts (Table 7).

\begin{tabular}{|l|l|l|}
\hline S.No & Analyst-1 & Analyst-2 \\
\hline Sample -1 & 99.1 & 98.5 \\
\hline Sample -2 & 98.9 & 100.2 \\
\hline Sample -3 & 98.7 & 99.2 \\
\hline Sample -4 & 98.9 & 98.6 \\
\hline Sample -5 & 98.8 & 99 \\
\hline Sample -6 & 98.8 & 100.6 \\
\hline Average & 98.9 & 99.4 \\
\hline SD & 0.14 & 0.86 \\
\hline \%RSD & 0.14 & 0.87 \\
\hline Overall Avg & 99.1 & \\
\hline Overall SD & 0.64 & \\
\hline Overall \%RSD & 0.65 & \\
\hline
\end{tabular}

Table 7: Ruggedness.

Robustness: Prepare the three samples and analyze under the conditions by changing the flow rate by $\pm 0.1 \mathrm{ml}$, wavelength $\pm 2 \mathrm{~nm}$, mobile phase $\mathrm{pH} \pm 0.2$ units and solvent composition $\pm 2 \%$. Evaluate the system suitability criteria. Calculate the \% RSD of \% Assay of three samples; calculate the overall \% RSD of \% Assay of nine samples between normal and variable condition (Table 8).

\begin{tabular}{|c|c|c|c|c|c|c|c|c|c|}
\hline \multirow{2}{*}{ ID } & Normal & Low flow & High flow & Low $\lambda \max$ & High Amax & \multirow{2}{*}{$\begin{array}{l}\text { At Low } \\
\text { pH } 6.3\end{array}$} & At High & Low com & High com \\
\hline & condition & $(0.9 \mathrm{ml} / \mathrm{min})$ & $(1.1 \mathrm{ml} / \mathrm{min})$ & $208 \mathrm{~nm}$ & $212 \mathrm{~nm}$ & & pH 6.7 & $(82: 9: 9)$ & $(78: 11: 11)$ \\
\hline Sample -1 & 99.1 & 99 & 100.5 & 98.6 & 98.8 & 99 & 98.2 & 100.3 & 99.4 \\
\hline Sample -2 & 98.9 & 99.5 & 101 & 99.7 & 99.2 & 98.6 & 98.1 & 99.1 & 99 \\
\hline Sample -3 & 98.7 & 98.9 & 100.5 & 98.5 & 100.9 & 98.9 & 98.4 & 99.7 & 99.5 \\
\hline Sample -4 & 98.9 & - & - & - & - & - & - & - & - \\
\hline Sample -5 & 98.8 & - & - & - & - & - & - & - & - \\
\hline Sample -6 & 98.8 & - & - & - & - & - & - & - & - \\
\hline Average & 98.9 & 99.1 & 100.7 & 98.9 & 99.6 & 98.8 & 98.2 & 99.7 & 99.3 \\
\hline SD & 0.14 & 0.32 & 0.29 & 0.67 & 1.12 & 0.21 & 0.15 & 0.6 & 0.26 \\
\hline$\%$ RSD & 0.14 & 0.32 & 0.29 & 0.67 & 1.12 & 0.21 & 0.16 & 0.6 & 0.27 \\
\hline Overall Avg & - & 99 & 99.5 & 98.9 & 99.1 & 98.9 & 98.7 & 99.1 & 99 \\
\hline Overall SD & - & 0.24 & 0.92 & 0.35 & 0.69 & 0.15 & 0.34 & 0.52 & 0.28 \\
\hline Overall\%RSD & - & 0.24 & 0.92 & 0.36 & 0.69 & 0.15 & 0.35 & 0.53 & 0.28 \\
\hline
\end{tabular}

Table 8: Robustness. 


\section{Results and Discussion}

The HPLC method was developed and validated of pregabalin and determination of pregabalin in capsule dosage form. It was validated for Specificity, accuracy, precision, linearity, solution stability, ruggedness, robustness and system suitability. Detail results of each parameter as shown in Table 9.

\begin{tabular}{|c|c|c|c|}
\hline S.No & Validation Parameters & Acceptance Criteria & Results/Conclusion \\
\hline 1 & Specificity (Selectivity) & $\begin{array}{l}\text { No peak shall be eluting at the retention } \\
\text { time of Pregabalin peak in blank and } \\
\text { placebo. }\end{array}$ & $\begin{array}{l}\text { No peaks eluted at the retention of } \\
\text { Pregabalin peak in blank and placebo. }\end{array}$ \\
\hline 2 & Forced degradation & $\begin{array}{l}\text { No peak shall be eluting at the retention } \\
\text { time of Pregabalin peak upon forced } \\
\text { degradation. Purity index of Pregabalin } \\
\text { peak shall pass. }\end{array}$ & $\begin{array}{l}\text { No peaks eluted at the retention time of } \\
\text { Pregabalin peak upon forced } \\
\text { degradation. Purity index of Pregabalin } \\
\text { peak passes. }\end{array}$ \\
\hline 3 & Linearity and range & $\begin{array}{l}\text { Correlation coefficient ' } r \text { ' should not be } \\
\text { less than } 0.99 \text {. }\end{array}$ & $\begin{array}{l}\text { Correlation coefficient ' } r \text { ' was within the } \\
\text { specified limit. }\end{array}$ \\
\hline 4 & Accuracy (Recovery) & $\begin{array}{l}\% \text { Recovery in each level of } \\
\text { concentration and mean recovery shall } \\
\text { be between } 98.0-102.0 \text {. }\end{array}$ & $\begin{array}{l}\% \text { Recovery in each level and mean } \\
\text { recovery was within the specified limits. }\end{array}$ \\
\hline 5 & System Precision & $\begin{array}{l}\text { Tailing factor shall be not more than } 2.0 \text {. } \\
\text { Theoretical plate shall be not less than } \\
1500 . \% \text { RSD of Pregabalin peak area } \\
\text { shall be not more than } 2.0 \text {. }\end{array}$ & $\begin{array}{l}\text { Tailing factor is } 1.04 \\
\text { Theoretical plate is } 9704 \\
\text { \%RSD is } 0.10\end{array}$ \\
\hline 6 & Method Precision & $\begin{array}{l}\% \text { RSD of \% Assay shall be not more } \\
\text { than } 2.0 \text { of six samples. }\end{array}$ & \% RSD is 0.14 \\
\hline 7 & Stability in analytical solution & $\begin{array}{l}\text { Sample solution will be considered } \\
\text { stable from the time of preparation, up } \\
\text { to the correlation of } \% \text { Assay at different } \\
\text { time interval sample against initial } \% \\
\text { Assay lies between } 0.98-1.02 \text {. }\end{array}$ & $\begin{array}{l}\text { Solution is stable up to } 24 \mathrm{hrs} \text { from the } \\
\text { time of preparation. }\end{array}$ \\
\hline 8 & Ruggedness & $\begin{array}{l}\text { System suitability criteria shall pass. } \\
\text { a) \% RSD of } \% \text { Assay shall be not more } \\
\text { than } 2.0 \text { of six samples. } \\
\text { b) Overall \% RSD of \% Assay shall be } \\
\text { not more than } 2.0 \text { of twelve samples } \\
\text { between two analysts. }\end{array}$ & $\begin{array}{l}\text { A system suitability criterion passes. } \\
\% \text { RSD is } 0.87 \\
\text { Overall \%RSD is } 0.65\end{array}$ \\
\hline 9 & Robustness & $\begin{array}{l}\text { System suitability criteria shall pass at } \\
\text { each variable condition. } \\
\text { a) \% RSD of } \% \text { Assay shall be not more } \\
\text { than } 2.0 \text { of three samples } \\
\text { b) Overall \% RSD of } \% \text { Assay shall be } \\
\text { not more than } 2.0 \text { of nine samples } \\
\text { between normal and variable condition. }\end{array}$ & $\begin{array}{l}\text { A system suitability criterion passes at } \\
\text { each variable condition. } \\
\% \text { RSD of \% Assay of three samples \& } \\
\text { Overall \% RSD of \% Assay of nine } \\
\text { samples between normal and variable } \\
\text { condition was within the specified limit. }\end{array}$ \\
\hline
\end{tabular}

Table 9: Results and Discussion

\section{Conclusion}

A simple, rapid, specific, precise and accurate HPLC method has been developed for the estimation of Pregabalin in bulk drugs and its capsule dosage forms. The test method is validated for Specificity (Selectivity), Linearity (Range), Precision (System, Method), Accuracy (Recovery), Ruggedness, Stability of analytical solution, Filter suitability and Robustness, found to be within the specified limit. The HPLC method for the determination Assay in Pregabalin capsules is accepted as valid since it complies with the requirements for Specificity, system suitability, Accuracy (recovery), Linearity and range, method precision, Ruggedness (intermediate precision), Robustness, Stability of analytical solution and Filter suitability. The influence of Acid, Alkaline, Oxidative Stress, Photolytic stress, Thermal stress, and Humidity stress conditions on Pregabalin was studied.
Results indicated that Pregabalin is stable under the experimental conditions. The proposed method has been successfully used for the routine analysis for the determination of Assay in Pregabalin capsules.

\section{Acknowledgement}

The authors are thankful to Kopran Ltd., Village Savroli, Taluka: Khalapur, Khopoli, District: Raigad, Maharashtra, India for providing me the best facilities including the drugs, all chemicals \& reagents for completion of this work.

\section{References}

1. Bhatacharya K, Sen P, Ray A (1994) Pharmacology and Toxicology 2:192. 
Citation: Seema A, Jeeja P and Ashish J (2016) Development and Validation of HPLC Method for Estimation of Pregabalin in Bulk \& Capsule Dosage Form. Pharm Anal Acta 7: 492. doi:10.4172/2153-2435.1000492

Page 6 of 6

2. Donald JA, Burgers (2003) Medicinal Chemistry and Drug discovery (6th edn) Wiley, New Jersey: 312-313.

3. Warner G, Figgitt DP (2005) Pregabalin as Adjunctive Treatment of Partial Seizures. CNS Drugs 19: 265-272.

4. Dworkin RH, Kirkpatrick P (2005) Nat Rev Drug Discov.

5. (2010) Indian Pharmacopeia (6th edn), Ghaziabad.

6. Taylor CP, Angelotti T, Fauman E (2007) Prevalence of acute repetitive seizures (ARS) in the United Kingdom. Epilepsy Res 73: 137.

7. Fink K, Meder W, Dooley DJ, Gothert M (2000) Inhibition of neuronal $\mathrm{Ca} 2+$ influx by gabapentin and subsequent reduction of neurotransmitter release from rat neocortical slices. Br J Pharmacol 130: 900

8. Van Hooft JA, Dougherty JJ, Endeman D, Nichols RA, Wadman WJ (2002) Eur J Pharmacol 449: 221.

9. Agarwal S, Bose A, Bhaumik U, Ghosh D (2008) Determination of Pregabalin in Human Plasma using LC/MS/ MS, Chromatographia 67: 237-243.

10. Taylor CP, Angelotti T, Fauman E (2007) Pharmacology and mechanism of action of pregabalin: the calcium channel alpha2-delta (alpha2-delta) subunit as a target for antiepileptic drug discovery. Epilepsy Res 73 . 137-150.
11. Dworkin RH, Kirkpatrick P (2005) Improving R\&D productivity, Nat Rev Drug Discov 4: 455-456.

12. Crofford LJ, Rowbotham MC, Mease PJ (2005) Pregabalin for the treatment of fibromyalgia syndrome: Results of a randomized, doubleblind, placebo-controlled trial. Arthritis Rheum 52: 1264-1273.

13. Siddall PJ, Cousins MJ, Otte A, Griesing T et al (2006) Neurology 67: 1792.

14. Anonymous (2005) Schedules of controlled substances: Placement of pregabalin in to Schedule V Final rule. Fed Regist 70: 43633-43635.

15. Beery D, Millington C (2005) Analysis of Pregabalin at Therapeutic Concentrations in Human Plasma/Serum by Reversed-Phase HPLC. Ther drug moni 27: 451-456.

16. Gujral RS, Haque SKM, Shanker P (2009) Int J of Biomed Res 5: 1-6.

17. Onal A, Sagiril A (2009) Spectrochimica Acta Part A: molecular and biomedical spectroscopy 72: 68-71.

18. Ashu M, Parmar S, Nagarajan K, Singh V (2011) Development and validation of rapid HPLC method for determination of Pregabalin in bulk drug and capsule dosage forms. Der Pharma Chemica 3: 482-489. 